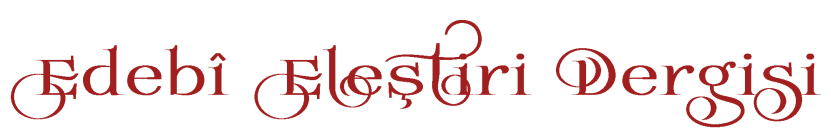

\author{
(Journal of Literary Criticism) \\ ISSN: 2602-46I6 \\ Cilt III, Sayı I, Mart 2019
}

YÜKLENME TARİHI: 0I.03.20I9 KABUL TARİH: 1 5.03.20I9 YAYIN TARİHİ: 27.03.20I9

Künye: Arslan, Mustafa Uğurlu (2019). "Klasik Türk Edebiyatında Şahin Giray Üslubu, Edebî Eleştiri Dergisi, c. 3/1, s. 1-14. DOI: 10.31465/eeder.534550

\author{
Dr. Öğr. Üyesi Mustafa Uğurlu \\ ARSLAN \\ Dicle Üniversitesi Edebiyat Fakültesi \\ Türk Dili ve Edebiyatı Bölümü \\ mustafaugurlum@gmail.com \\ ORCID ID: 0000-0003-2542-5040
}

\section{KLASİK TÜRK EDEBIYYATI'NDA ŞAHİN GİRAY ÜSLUBU}

\author{
ŞAHIN GIRAY STYLE IN \\ CLASSICAL TURKISH \\ LITERATURE
}

\section{ÖZ}

Edebî metinlerde; dil, ifade ve üslup birbiriyle yakından ilintili terimler olarak karşımıza çıkmaktadır. Bir metnin edebî dilinin özelliklerini bilmek aynı zamanda onun üslup özelliklerini de tespit etmemize yardımcı olur. Bununla birlikte şairlerin seçtiği kelimelerin kendi muhayyilelerinde nasıl şekillendiğini belirlemek oldukça güçtür. Klasik şiirimizde şairler kendi üsluplarını oluştururken zaman zaman şiirlerine "müdevver", "müşeccer" gibi görselliği de katmışlar ve kendilerine has bir üslup oluşturma temayülü içerisine girmişlerdir. Klasik Türk şiirinde Nedîmâne tarz ya da Levendâne tarz şiirler kaleme alındığı gibi "Şahin Giray Üslubu" olarak adlandırılan ve bu üslubu hususiyle şekilsel olarak taklid etmek suretiyle oluşturulan şiirlerin yazıldığ 1 da görülmektedir. $\mathrm{Bu}$ çalışmada "Şahin Giray Üslubu"nun nasıl oluștuğu ve klasik edebiyatımızda hangi şairlerin bu üslubu benimsediği örnekleri ile birlikte ele alınmıştır. Anahtar Kelimeler: Üslup, tarz, Şahin Giray Üslubu, dîvân şiiri, Klasik Türk Edebiyatı.

\begin{abstract}
In literary texts; language, expression and style appear as closely related terms. Knowing the features of the literary language of a text also helps us to determine the features of the style. Nevertheless, it is very difficult to determine how the words chosen by the poets are shaped in their imagination. In our classical poetry, the poets occasionally added visuality as well as "müdevver," "müşeccer" in their poetry while establishing their styles and had the inclination to create an idiosyncratic form of style. In classical Turkish poetry, it is seen that the poems named as "Şahin Giray Style," which were written in Nedîmâne or Levendâne style and formed by imitating this style formally in particular, were written as well. In this study, how the "Şahin Giray Style" was formed and which poets adopted this style in our classical literature are discussed along with examples.
\end{abstract} Keywords: Style, form, Şahin Giray Style, Ottoman Poetry, Classical Turkish Literature.

\title{
Giriş
}

İslâmiyetin kabulünden sonra özellikle XIV. yüzyılın başlarından XIX. yüzyılın sonlarına kadar etkisini sürdüren dîvân edebiyatının genel olarak gelişim sürecine bakıldığında Türkî-i Basit, Klasik Üslup, Sebk-i Hindi ${ }^{1}$ gibi muhtelif üslupların ortaya çıktığı görülmektedir. Bu üsluplar, bazen bir asrı etkisi altına alabildiği gibi bazen de yansımaları birkaç şairle sınırlı kalmıştır. "Türk̂̂̂i Basît, Köprülüzâde Mehmed Fuad'ın 1928 yılında 16. yüzyıl şairlerinden Edirneli Nazmînnin Dîvânını ortaya çıkarmasıyla, bugüne kadar bir tek bu şairin dîvânında görülen bazı şiirlerin başlı̆̆ında kullanılan bir adlandırmadır” (Mermer, 2006: 11). Her ne kadar son zamanlarda yapılan akademik çalışmalarda Türkî-i Basît'in bir

\footnotetext{
${ }^{1}$ Bk. Ali Fuat Bilkan, Şadi Aydın, Sebk-i Hindi ve Türk Edebiyatından Hint Tarzı, 3F Yayınları, 2007, İstanbul; Ahmet Mermer, Türkî̀i Basît ve Aydınlı Visâlî'nin Şiirleri, İsrafil Babacan, Türk Şiirinin Sonbaharı Sebk-i Hindi, Akçağ Yayınları, 2012, Ankara; Hüseyin Yorulmaz, Dîvân edebiyatında Nâbî Ekolü, Kitabevi Yayınları, 1996, İstanbul, Hasibe Mazıŏlu, Nedim'in Divan Şiirine Getirdiği Yenilikler, Akçağ Yayınları, 2012, Ankara.
} 
akım olduğu tartışılagelmiş ${ }^{2}$ ise de bu tezahürlerin bazen de "Nâbî ekolü ya da Nedîmâne tarz" şeklinde şairin hususi üslup tarzına göre teşekkül ettiği görülmektedir. Tetkik ettiğimiz mecmua ve dîvânlarda karşılaşttğıııı bir üslup tarzı da “Şahin Giray Üslubu”dur. Kırım'ın Osmanlı Devleti'ne bağlanmasından sonra dîvân edebiyatı Kırım'da da etkisini göstermiș, Kıpçak Türkçesi ile gelișen Kırım Türk Edebiyatı daha sonra İstanbul Türkçesinin etkisi altına girerek halk ve dîvân edebiyatı şeklinde iki koldan gelişimini sürdürmüş, çok sayıda şair ve ilim adamı yetişmiştir. Yapılan araştırmalarda hanlık döneminde yaşamış 54 Kırımlı şairin olduğu dile getirilmektedir (Kurnaz, Çeltik, 2000, 237). Bu gelişimde özellikle Kırım'ın 1248 (1832) yılında Giraylar soyunun idaresinde bir hanlık haline gelmesi ve I. Mengli Giray, Saadet Giray, Gazi Giray Han ve Şahin Giray Han gibi Kırım Hanlarından çoğunun şair olmasının etkisi oldukça büyüktür.

Şahin Giray ve onun edebî şahsiyeti ile ilgili birincil kaynaklarda çok fazla bilgi bulunmamaktadır. İsmail Beliğ'in Nuhbetü'l-âsâr li-Zübdeti'l-eş'âr adlı eserinde "Şahin Giray (ö.1712), şiirlerinde Şâhî mahlasını kullanmıştır. Kırım hanlarından Selim Giray'ın oğludur" (Belîğ, 1985:311). bilgisine yer verilmiştir. Sicill-i Osmânî'de ise Şahin Giray adında beş isimden söz edilmektedir. Bunlardan birincisi Saadet Giray'ın oğlu, ikincisi Selâmet Giray'ın kardeşinin oğludur. Üçüncüsü Selâmet Giray'ın kardeşinin oğlu, dördüncüsü Hacı Selim Giray Han'ın oğludur. Beşincisi ise Topal Ahmed Giray'ın oğlu ve Sahib Giray'ın kardeşi Şahin Giray'dır (Mehmed Süreyya, 1996:148-150). Şahin Giray ile ilgili Sicilli Osmanî de şu bilgilere yer verilmiştir: "Topal Ahmed Giray'ın mahdumu ve Sahib Giray'ın biraderidir. 1191(M. 1777)'de Kırım Hanlı̆gına Rusya'dan bir yaver ile geldi ise de hanlı̆̆ kabul buyrulmaylp Selim Giray gönderildi. Ancak takarrur edemeyip bu hanlikta kaldl. 1196 (M.1781)'de Kırım'dan tard olunup 1197 (M. 1783)'te tekrar han olarak Rusya'dan geldi. Rusya bu suretle Kırım'l alt edip bir miktar maaş verip Kırım'dan âhar bir mahalle gönderip iskan ettirdi" (Mehmed Süreyye, 1996: 14915). İslam Ansiklopedisi'nde ise Şahin Giray'ın hayatı ve eğitimi ile ilgili şu bilgilere yer verilmektedir: "1158'de (1745) Edirne'de doğdu. Kırım Hanı II. Devlet Giray'ın torunu olup babası Ahmed Giray'dır. Çocukluğu Edirne'de geçti, babasını küçük yaşta kaybedince annesinin gözetiminde öğrenim gördü. Bir süre Selfmik'te kaldı. Gençlik çă̆ında Venedik'e giderek burada Batı tarzında ĕgitim aldı, Italyanca ve Grekçe öğrendi, Batı kültürüne aşina oldu. Amcası Kırım Giray'ın hanlığı döneminde Kırım' a çağrıldı. Gülbün- i Hanan'da onun Çerkez emirlerinden Tamgan adlı birinin yanında yetiştiği; Kırım'a döndügünde ise Tuna ve Kuban nehirleri arasındaki düzlüklerde yaşayan Nogay kabileleri arasında bulunduğu belirtilir" (Emecen, 2010, 275-277). Kardeşi Sahip Giray Han zamanında kalgaylık yapmış olan Şahin Giray,1777 yılında Kırım Han'1 olmuş, 1778'de halkın ayaklanması sonrası Rusya'ya sığınmıştır. Daha sonra Osmanlı Devletince Rodos'a sürgüne gönderilen Şahin Giray bir süre sonra idam edilmiştir. ${ }^{3}$ Şâhî mahlasını kullanan Şahin Giray'ın şiirlerine bakıldığında dîvân şiirinin dil hususiyetlerine bağlı kaldığ 1

2 Bk., Hatice Aynur "Türkî-i Basît Hareketini Yeniden Düşünmek" Turkish Studies International Periodical For the Languages, Literature and History of Turkish or Turkic Volume 4/5 Summer 2009; Ziya Avşar, "Türkîi i Basit'i Yeniden Tartı̧̧mak, bilig-18/Yaz'2001.

${ }^{3}$ Bk. Şemsettin Sâmi, Kâmûsü 'l-A 'lâm C. IV, s.1740, Kaşgar Neşriyat. Ankara, 1996; Özer Şenödeyici, “Osmanlinin Görsel Şiirleri III, Trajedi’nin Gölgesinde Hüner Gösterisi”, Uluslararası Sosyal Araştırmalar Dergisi, The Journal of International Social Research, Volume 2/6 Winter 2009, s. 586592

\section{Edebî Eleş̧iri Dergisi \\ Cilt 3, Say1 1, Mart 2019}


ve siyasî alandaki başarısızlıklarına karşın, sanatkâr bir devlet adamı dehasını şiirlerinde gösterme çabası içerisine girdiği görülmektedir. Şemsettin Sâmî Şahin Giray'ın şairliği ile ilgili şu ifadelere yer vermektedir: "Tabiat-ı şi 'riyesi olup bazı eş 'ârı vardır' (Şemsettin Sâmi, 1996: 1740).

\section{Şahin Giray Üslubu}

Edebî bir metnin üslup açısından incelenmesi demek, "metin" adı verilen söz değerlerinin çok yönlü bir sistem içerisinde tetkik edilmesi demektir. "Üslup, bir edebî eserin yapısını oluşturan temel unsurlardandır. Edebî eser incelenirken "nasıl yazllmuş sorusuna" verdiğimiz cevap, üslubun hüviyetini teşkil ederek onu teşhis etmemizi sağlar. Bu hüviyet, sebk, üslup, reviş, tarz, biçem gibi farkl kelimelerle ifade edilse de sonuçta aşağı yukarı aynı anlam doğrultusunda bir göstergeye işaret eder" (Babacan, 2012: 17). Bir metnin anlam dünyasına nüfuz etmek, edebî metnin malzemesi olan dile de nüfuz etmeyi gerektirmektedir. Dolayısıyla üslubu dilden ayrı düşünmek mümkün değildir. Dîvân şiirinin tekâmül çizgisinde üsluplar meselesine bakıldığında daha ziyade, kullanılan kelimeler, söz gurupları, şairlerin ifade vasıtası olarak kullandıkları kelimelerin anlam evreni ve ifade benzerlikleri dikkate alınarak çeşitli sınıflandırmaların yapıldığı, buradan hareketle bütün bir edebî anlayışın üslubundan söz etme temayülü içerisine girildiği görülmektedir. Üslupla ilgili kanaatlerini bildiren tezkire müellifleri "hûb, nâzik edâ, latîf" gibi bazı terimleri kullansa da belâgat kitaplarımız da dahil olmak üzere Recâizâde Mahmud Ekrem'in Talim-i Edebiyat adlı eserine kadar yukarıda ifade ettiğimiz manada bir üslup tanımı içerisine girmedikleri görülmektedir.

Klasik Türk şiiri içerisinde görsel şiirlerin de neredeyse bir gelenek oluşturacak derecede belli bir yekûn teşkil ettiği ve bir ifade tarzına/üsluba dönüştüğü görülmektedir. Görsel şiir, genel olarak şairin daha önce yazılan şiir tarzlarından farklı olarak kullandığı kelime deneyleri üzerine kurduğu şiirdir. Estetik bir kayg1 güdülerek oluşturulan bu şiirin amac1 ise "Dili geri plandaki görüngülerden kurtararak kendi boyutları içinde gören şiir türü, hep anlatımda yeni olanaklar arama, eski kalıplardan kurtulma, görme yetisini de şiire sokma yolundaki çabaların ürünü” (Tökel, 2000: 16-17). olarak değerlendirilmektedir. Son dönemlerde dîvânlar ve şiir mecmuaları ile ilgili şekil açısından yapılan araştırmalar, dîvân şiirinin biçim ve hünere dayalı keşfedilmemiş birçok yönünü ortaya çıkarmaktadır.

"Üslup" terimini sadece bir edebiyat terimi olarak değil mimari, resim ve musiki gibi geniş yelpazeli bir terim olarak değerlendirdiğimizde, Şahin Giray'ın şiiri, görme duyusuna ait algılamaların ifade biçimleri şeklinde tasarlandığ 1 ve Giray'ın kendisine has bir üslup/tarz oluşturduğu kanaatimizi güçlendirmektedir. Nitekim üslup, Sanat Terimleri Sözlügü’nde; "Bir devrin ya da bir sanatçının kişiliği, yani teknik, renk, kompozisyon, biçim ve anlatım bakımından özellikleri, üsluplaştırma ise hakiki şekil ve motiflerin karakterini kaybettirmeden birleştirerek tezyini ve şematik hale sokmak" (Turani, 1980:129). şeklinde tanımlanmaktadır. Aşağıda da ifade edileceği gibi klasik şiirimizde Şaban Kâmî gibi bazı şairler şiirlerine başlık olarak "Gazel-i ber- üslub-1 Şahin Giray” yazmışlardır. 
Şahin Giray; şiirlerinde mana kadar görselliğe de önem vermiş, her kelime için bir mühendis titizliği ile şiirini oluşturma çabası içerisine girmiştir. Dairesel olarak çizilmiş ve bir gülü andıran şiirlerinde merkezde yer alan harf, her dizenin ilk ve son harfini teşkil etmektedir. Ayrıca oluşturulan gazelin her beytinin son harfi tersinden okunduğu zaman, sonraki beytin ilk misraının ilk kelimesini oluşturmaktadır. İç içe geçmiş yarım dairelerin kesişen kısımlarında yer alan kelimeler ise, şiirin kesişen tüm dizelerinde ortak olarak kullanılmaktadır. Şekil ve imge varlığın ezoterik bir kanıtı ise, Şahin Giray'ın zihin ve kalp gözüyle deneyimlediği müdevver gazeli de manaların simgeleri hükmündedir denilebilir. Ayrıca her beytin merkezde bulunan bir harften başlayıp dairesel olarak aynı merkezde aynı harfle bitmesi akla tasavvuftaki devir nazariyesini getirmektedir. Çünkü tasavvuftaki "devr" yani dönme metaforu, varlıkların yaratılış serüveni ile ilgili birtakım mecaz ve istiareleri barındırmaktadır. Şahin Giray Üslubu ile yazılmış şiirlerdeki dairesel göstergeler, varlıkların yaratılış itibari ile "Kavs-i nüzul ve Kavsi uruc" ile ifade edilmeye çalışlan helezonik ve döngüsel uyumu sembolize ediyor gibidir. Nitekim bu döngü "Allah'tan geldik, yine Allah'a döneceğiz" (Bakara 2/156) meâlindeki âyetin bir yerde şekille ifade edilmesidir. Çünkü devir nazariyesine göre her şey O'ndan başlar ve yine O'na döner.

Şahin Giray'ın zikredilen şekilde yazmış olduğu bir gazelini Ali Çavuşoğlu "Kırım Hanı Şahin Giray (ö. 1787) ve "Gazel-i Müdevver 'i” başlıklı bir makalesinde tanıtmıştır. Şahin Giray’ın müdevver gazelinin Kırım Türkçesi’nin, Osmanlı edebî diline ne kadar bağlı olduğunun en güzel örneklerinden biri olduğunu ifade eden Çavuşoğlu, dairesel olarak, bir gül ya da papatyayı andıran aşağıdaki gazelin de yukarıda ifade edildiği gibi merkezdeki (ى) harfinin, her dizenin hem ilk hem de son harfi olduğunu ifade etmektedir. (Çavuşoğlu, 2010: 42). Gazellerdeki ustalı̆̆ 1 kavrayabilmek için metni Arap harfleri ile okumak gerekmektedir.

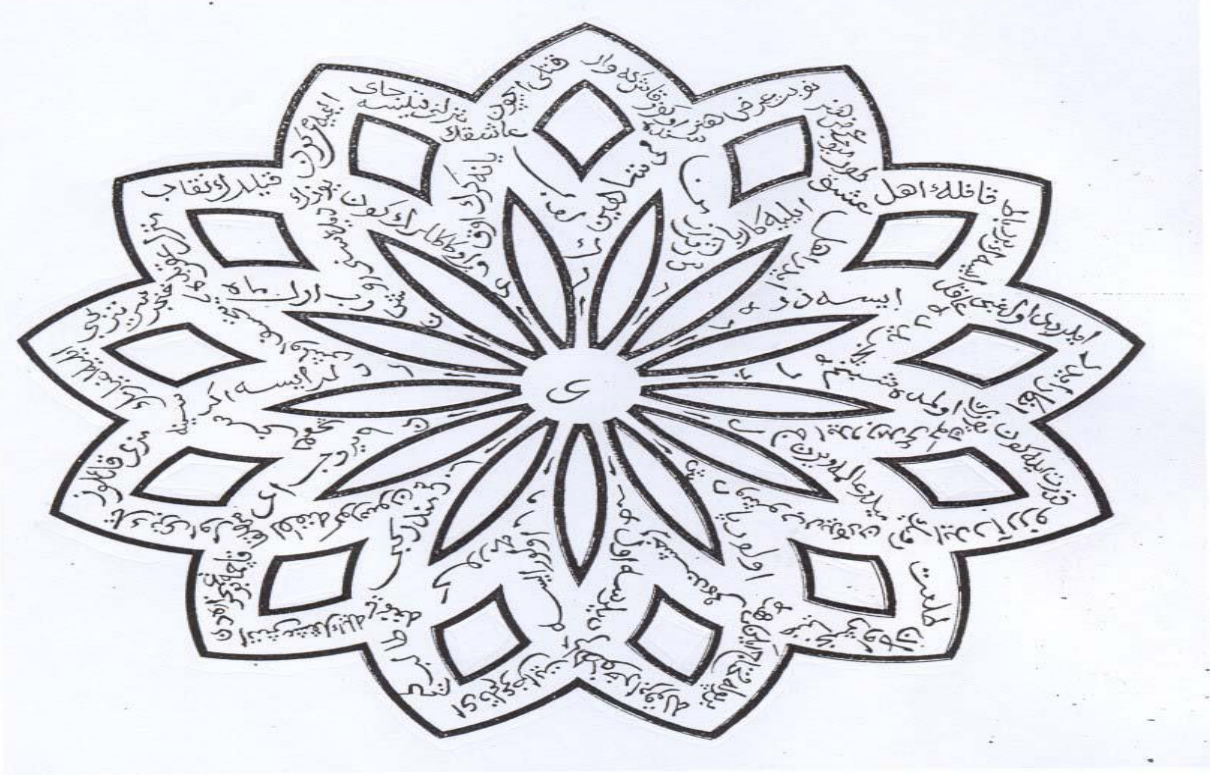




\section{Gazel-i Müdevver}

\section{(fâcilâtün/facilâtün/f' ilâtün/faclün)}

Yâr gelip âşııın menzilini kılsa cây

Etmeye mi gün yüzün dîdesini rûşenây

Yanaşıp ol mâh ya hançer-i ser-tîz gibi

Eyleye agyârımın sînesini hemçü nây

Yan verip ey meh-likâ kaçma bu gam-hordan

Âteş-i 1şkın ile yanmaga görme revây

Yâver olursa eger lutf-1 Hudâ bir kula

Bir pula muhtâc iken dehre olur pâdişây

Yaş düşüp dîdeden rûyun eder arzû

Kudret ile gün yüzün olmada şebnem-rubây

Yap reh-i tecrîdde âkıl isen bir ribât

Kâfile-i ehl-i 1şk eyleye kârbân-serây

Yâr-i ser-firâz-1 men sende o göz kaş ki var

Katli için âşıgın ya ne gerek ok u yay

Yayıp o kâküllerin gün yüzün kıldın nikâb

Menzil-i akrebde ya münkesîf olmuşdur ay

Yâr deler ise eger sînemizi kâiliz

Tek bizi ol meh-likâ lutfuna görsün sezây

Yaz semender gibi yanmaga tâlib kim

Ey kalem arz et eger diler ise ol Humây 
Ya meh-i rahşende mi dehre ziyâ-bahş olan

Tal'at-i rûyun mudur âleme viren cilây

Yâ lec edip müddaî gün yüzün inkâr eder

Eyleridi ol gabî âkıl ise zerre ra'y

Yâra ider ehl-i 1şk durmayıp arz-1 hüner

Nevbet-i arz-1 hüner sende mi Şâhin Girây (Çavuşoğlu, 2010: 42-43)

Yukarıdaki şiirin her beyitinin başı ve sonu (ى) harfiyle başlayıp (ى) harfi ile bitmektedir. Ayrıca "rûşenây" (رو شد ناي) kelimesi tersten okunduğu vakit sonraki beyitin ilk kelimesin ilk hecesini (يُ ان) oluşturmaktadır.

İfadenin yanı sıra görsel estetiği de dikkate alarak şiirlerini oluşturan Şahin Giray'ın yukarıda çiçek ya da papatya şeklinde verilen aynı gazeli bir başka mecmuada dairesel şekliyle yeniden istiflenmiştir. Görsel şiirler üzerine çalışan bir başka araştırmacı, aynı gazeli "Osmanlının Görsel Şiirleri III -Trajedinin Gölgesinde Hüner Gösterisi” başlığ ile neșretmiştir. Șenödeyici, makalesinde "Söz konusu şiir, bir büyük daire ve bu daireye iç içe geçirilmiş bir şekilde eklenen on üç yarım daireden oluştuğunu ve bunun bir hüner gösterisi olduğunu dile getirmektedir (Şenödeyici, 2009: 587-588).

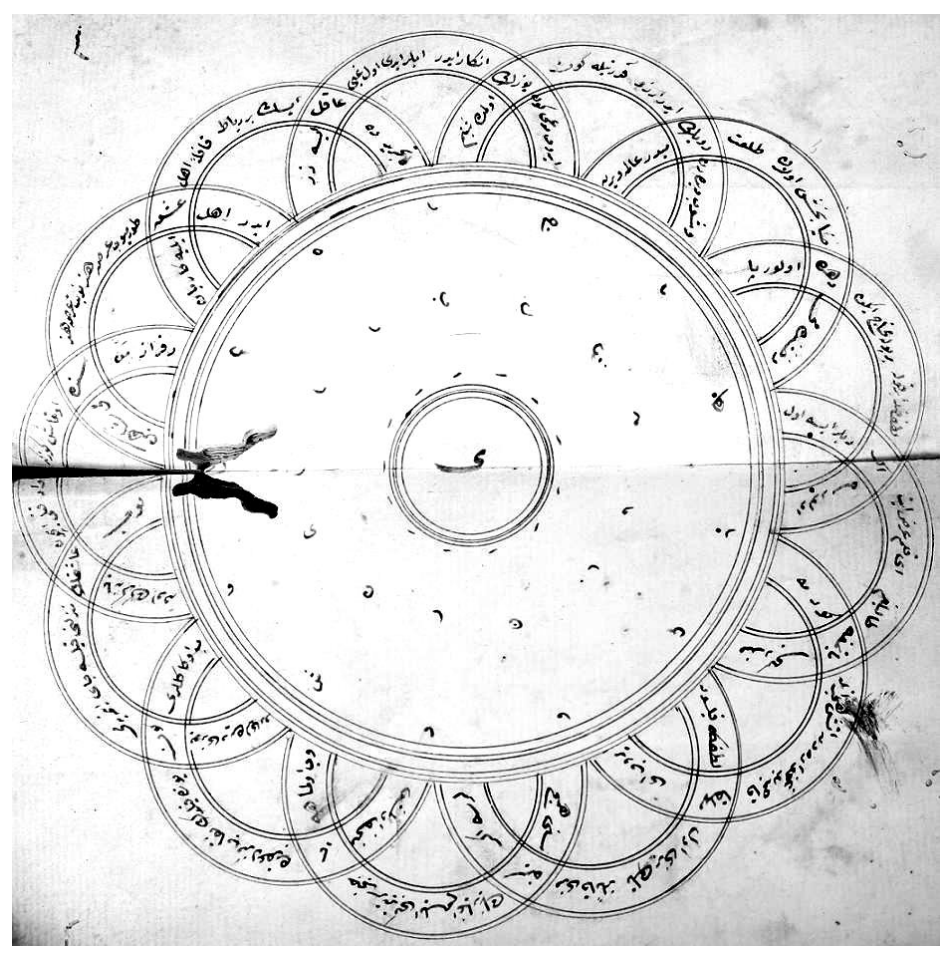

Şahin Giray Han'1n mükemmel denilebilecek boyutta söz ve şekli bir araya getirerek oluşturduğu gazelleri zaman içerisinde bazı şairleri de etkilemiş ve 
Ketencizâde Mehmed Rüştü Efendi, Diyarbekirli Şaban Kâmî Efendi gibi şairler Şahin Giray Üslubu/tarzıyla şiirler yazma gayreti içerisine girmişlerdir.

Ketencizâde Mehmed Rüştü Efendi (1836/1916) âlim, şair ve hattat gibi vasıflarla tavsif edilen mühim bir şahsiyettir. Başta mevlid-i şerif olmak üzere tasavvufî şiirler kaleme alan şair, Şahin Giray tarzıyla levha şeklinde gazel yazmıştır. Şairin el yazması levhası Sadi Çögenli'nin özel kütüphanesinde bulunmakta, bu müdevver ve musanna şiir iki bölümden oluşmaktadır. Üstteki bölüm bir gül şeklinde yarım dairelerin iç içe geçmesi ile istiflenmiş, ikinci bölüm ise alt kısımda bir saks1 görüntüsü ile meşkedilmiştir. Çiçek şeklindeki şiirin merkezinde bulunan dairede "nun" (ن) harfi yer almakta ve bu harf, şiirin tüm beyitlerinin başlangıç ve bitiş harflerini oluş̧urmaktadır. Ketencizâde, dîvânında ustalıkla yazmış olduğu şiiri çözümleyebilenler için şu duada bulunmaktadır:

Bakıp devriyeme kim kılsa dikkat

Hudâ'dan her cihânda bula izzet (Elmalı, 2015:53)

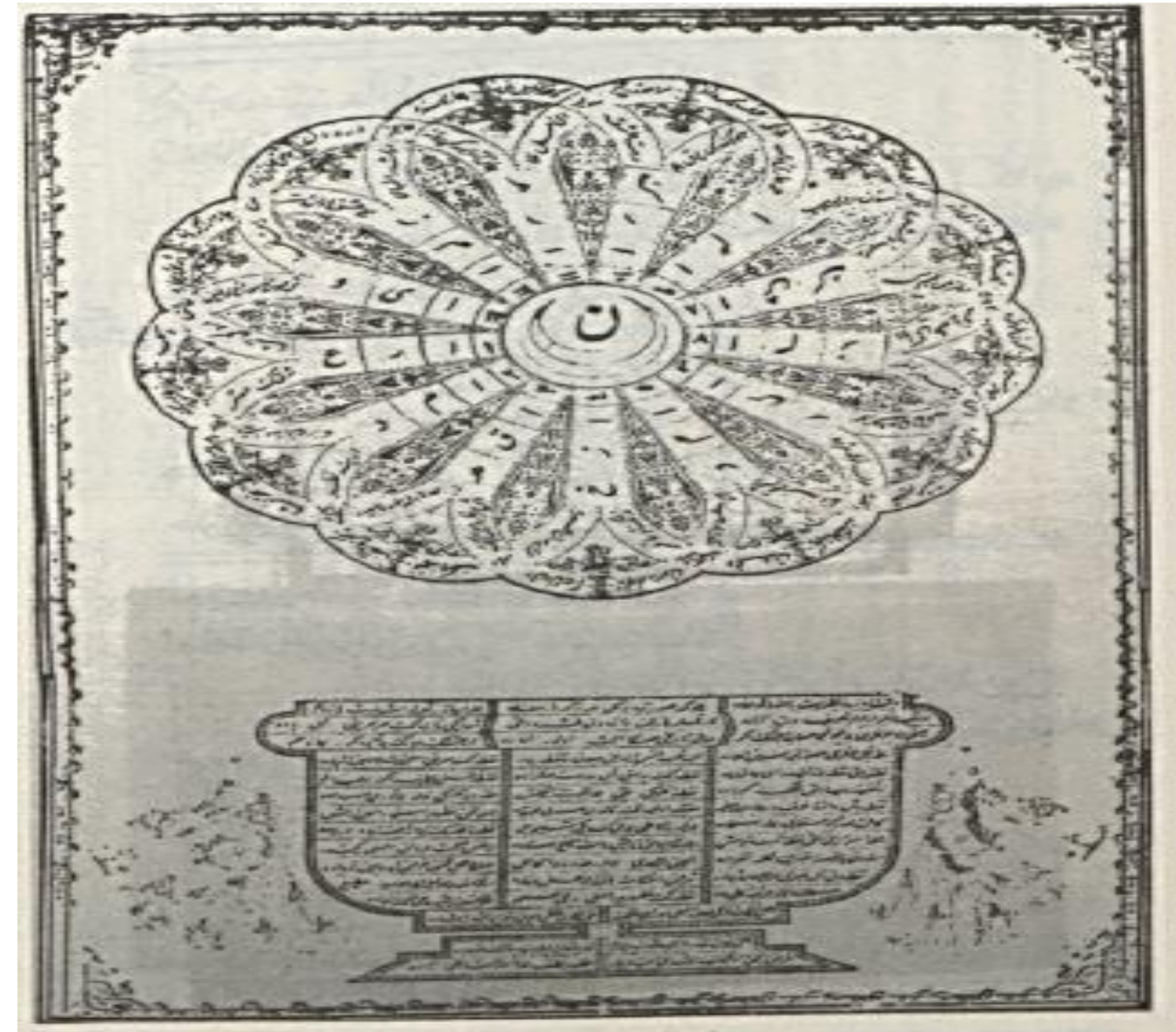




\section{(fâcilâtün/fa' ilâtün/fac ilâtün/fa' lün) ${ }^{4}$}

Nâr-1 ' aşkın setr ederdim dilde ey mahûb-1 Hak

Halk ifşâ etmek ister dem-be-dem dîdemde kan

Nâka-veş her hâre meyl etmek dil dedim

İncelirsin rişte-tek münkîr olur hep şâdumân

Nâmdârına nazar etmek ne mümkün âşıkın

Gonca-i vaslın dilerler ermeden ömre hazân

Nâz-1 handânın umanlar rişte-tek incelmeden

Peyk-i lutfun anlara olsa n'ola müjde-resân

Nâs rumûz-1 aşktan gâfildir ey mihr-i münîr

Gün doğanda nâ-bedîd olmaz mı necm-i kehkeşân

Nâ-şekib olmuş ise ger iyd-i vasla âşıkın

Ta'n olunmaz çünki hicrin gibi yok bâr-1 girân

Nâr-1 kürbet âşıka söyler ki Hak’tan bil beni

Çâresinde âciz olmuştur etibbâ-yı zamân

Nâ-mizâc-1 aşk olan ister mi çâre özgeden

Rüşdi-i bî-çâre âşıktır değil ez-şâirân

\footnotetext{
${ }^{4}$ Çalışmamıza almış olduğumuz Ketencizâde Mehmed Rüştü Efendi’nin bu gazeli Naci Elmalı'nın hazırlamış olduğu eserden (Elmalı, Naci; Ketencizâde Ahmed Rüşdi Efendi, Atatürk Üniversitesi Yayınları, 2015, Erzurum.) alınmıştır, ancak eserde gazeldeki beyitler Şahin Giray Han'ın üslup tarzına göre sıralanmamıştır. Her beyitin sonundaki kelime tersten okunduğunda sonraki beyitin ilk kelimesini oluşturacak şekilde tertip edilmesi gerektiğinden gazelin beyit tertibi tarafımızdan yeniden oluşturulmuştur.
}

\section{Edebî Eleş̧iri Dergisi \\ Cilt 3, Say1 1, Mart 2019}


Nâra cân attıysa ger pervâne-i âciz dertten

Âşık-1 sâdık olur mu râhat-ı nefse uyan

Nây-veş sûrâh olmayan âş̧ı değil

Cân-1 âşı terkeder etmez özün ez-nâdümân

Nâm-1 Zîbânı duyanlar nâ-be-dîd eti kamu

Her ne varı var ise senden dilerler hep emân

(Elmal1, 2015:53)

Yukarıdaki beyitlerde Şahin Giray'ın şiir tarzına uygun olarak her beyit (ن) harfi ile başlayıp (ن) harfi ile bitmiştir. Aynı şekilde yukarıda verilen Şahin Giray'ın şiir örneklerinde olduğu gibi her beyitin sonu tersten okunduğunda ذناق/ (ق ان) sonraki beyitin ilk mısrasının ilk kelime ya da ilk hecesini oluşturmaktadır.

Şahin Giray üslubu ile şiirler yazan şairlerden birisi de Diyarbekirli Mehmed Şaban Kâmî Efendi'dir. Şaban Kâmî, XIX. yüzyılın başlarında Osmanlı Devleti’nin dağılma sürecinin hızlandığ doğmuş ve yaşamının büyük bir kısmını bu şehirde geçirmiş, H.1301/M. 1884'te Diyarbakır'da vefat etmiştir. Ali Emîrî Efendi, hem hocası hem de büyük amcası olan Şaban Kâmî'yi, onun vefatına düşürdüğü tarih manzumesinde "âlim, müfessir, muhaddis, fakih, hâfız, tecvidle Kur'an okuyabilen, mûsikîșinâs, șair, münșî, hattat, mutasavvıf, felsefeci, mantıkçı gibi sıfatlarla tavsîf etmektedir (Arslan, 2018: 36).

Musanna şekilde oluşturmaya çalıştığı gazellerinde "Şahin Giray Üslubu" ifadesini kullanan Kâmî, aşağıda örneği verilen manzumede öncelikle gazelin ilk mısraının ilk kelimesi "Ra" harfi ile başlamış ve ikinci mısraın son kelimesi "Ra" harfi ile bitmiştir. Bu tür şiirlerin benzerlerini Dursun Ali Tökel eserinde "Tautogram ve Dîvân Şiiri”" başlığı altında ele amış ve asgari ilk harfleri aynı olan kelimelerden kurulan metin olarak tanımlamıştır. (Tökel, 2000: 43) Ancak Kâmî’nin kendi ifadesi ile Şahin Giray üslubuyla yazmış olduğu şiirinin, Tautogram tarzlı şiirlerden farklılık arz ettiği görülmektedir. Kâmî, dîvânında Şahin Giray üslubu ile kaleme aldığı gazelini yazılı ve görsel olmak üzere iki şekilde oluşturmuştur.

Aşağıdaki gazelin başlığında şair "Gazel ber üslûb-ı Şahin Giray" ifadesine yer vermiş ve şiirini görsele aktarırken hangi kelimeler üzerinde tasarrufta bulunduğunun anlaşılması için belirlediği kelimelerin üzerini kalemle çizmiştir. Aşağıdaki metinde $(\jmath)$ harfi ile başlayıp $(\jmath)$ harfi ile biten kelimelerin üzeri çizildiği gibi, Şahin Giray'ın üslubuna uygun olarak her beyitin sonunda yer alan kelime tersten okunduğunda bir sonraki beytin ilk kelimesi ya da ilk hecesini oluşturması hasebiyle zikredilen kelimelerin de üzeri çizilmiştir. Ayrıca gazelde bazı mısraların ortasında bulunan kelimelerin de üzeri çizilmiştir. Bu kelimeler daireleri birbirine bağlayan ortak kelimelerdir. 


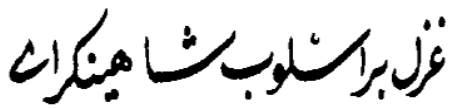

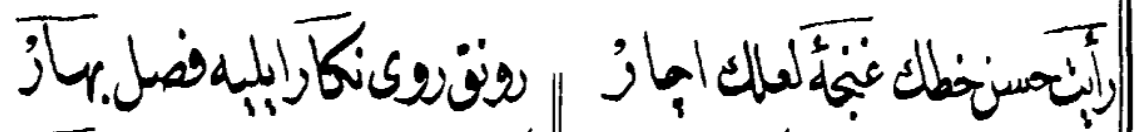

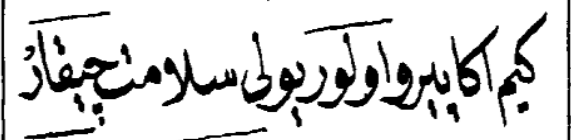

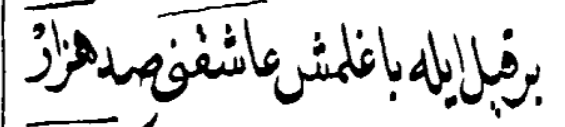

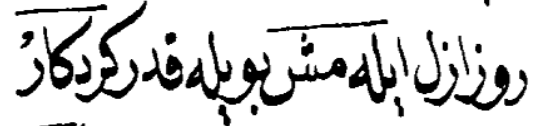

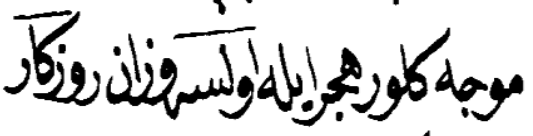

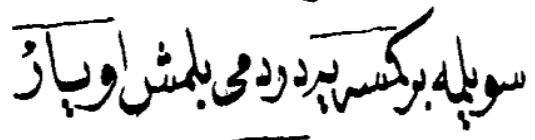

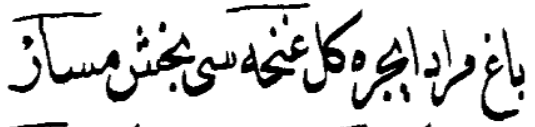

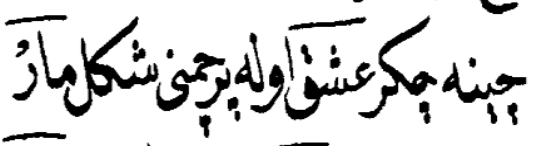

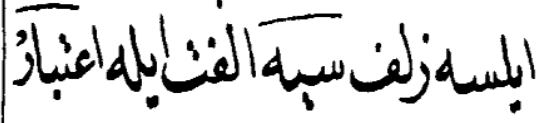

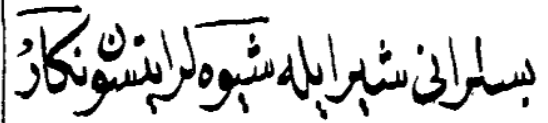

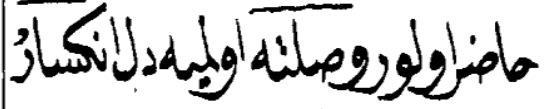

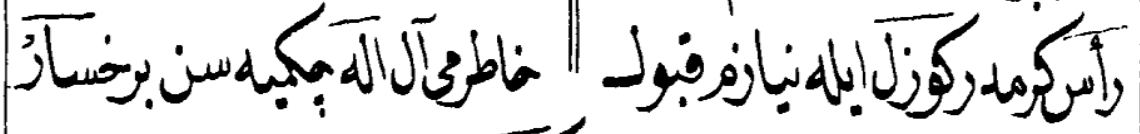

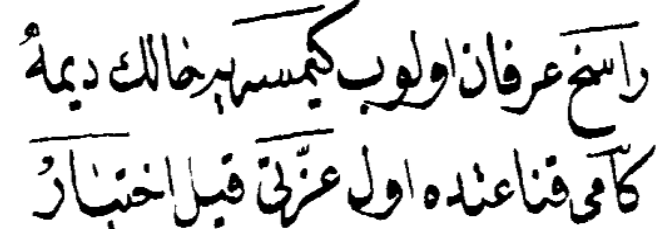


Yukarıda klasik manzum bir metin olarak verilmiş olan gazelin, kesişen sözcüklerin ayarlanması için şairin daha önceden şablonlar üzerinde belirli hesaplar yaparak mesai harcadığını düşündüğümüz görsele istiflenmiş hali ise aşağıda yer almaktadır.

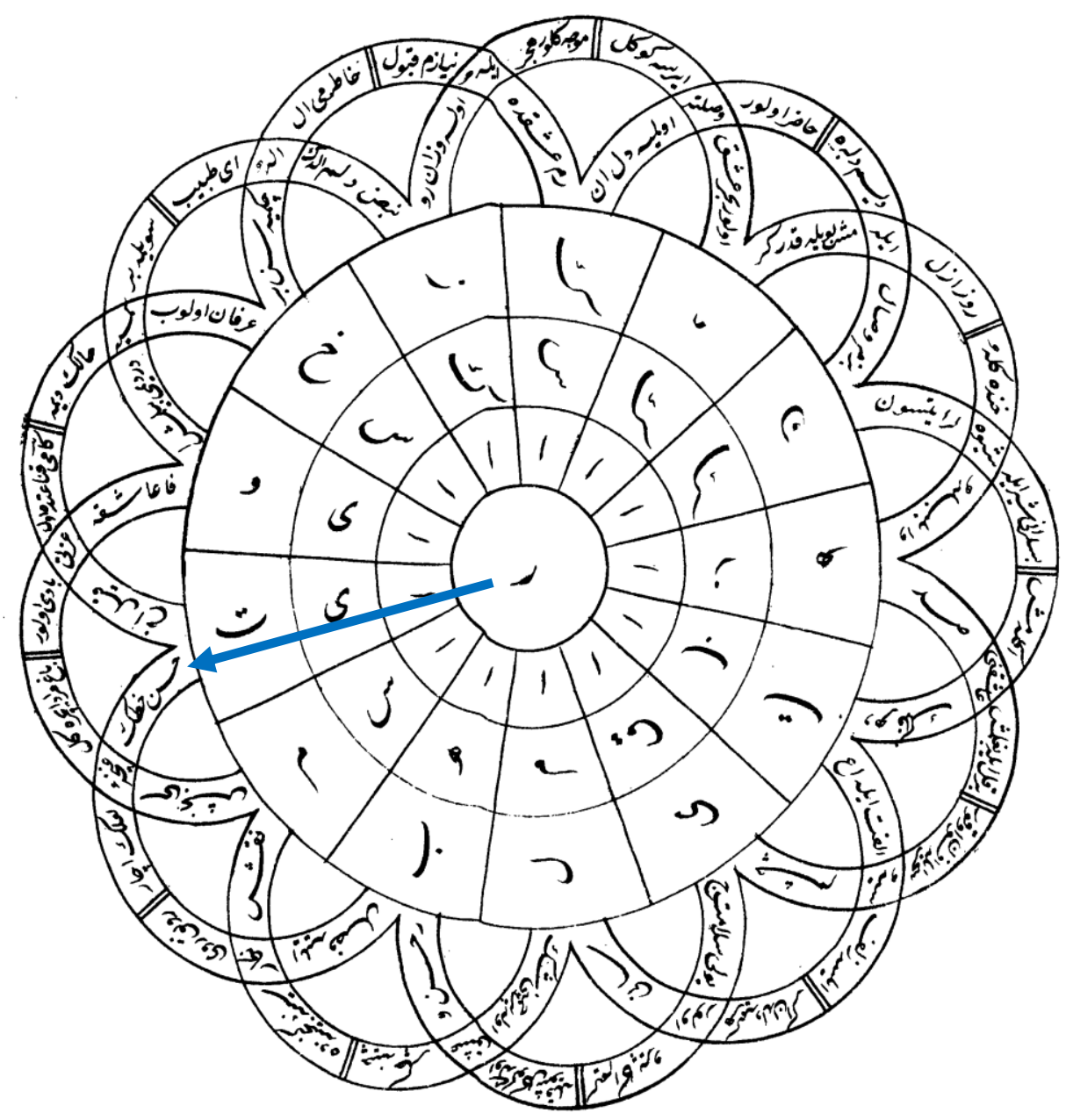

Kâmî’ye ait olan bu musanna/müdevver gazel örneği yukarıda belirtildiği gibi merkezdeki $(\jmath)$ harfinden okla gösterilen yöne doğru bir daire oluşturacak şekilde okunduğunda her daire bir beyit teşkil etmekte, art arda daire şeklinde yazılan bu beyitlerle Şahin Giray'ın şiirlerinde olduğu gibi görsel, sanatlı bir şiir vücuda getirilmektedir. Dairelerin kesişim noktasında bulunan kelimeler ise hem birinci beytin hem de kendisinden sonraki beytin ortak kelimesi olarak kullanılmaktadır. Buradan hareketle şiire yeniden bakıldığında gazelin tüm beyitleri $(J)$ harfi ile başlayıp (\lrcorner$)$ harfi ile bitmektedir. Her beytin son kelimesi tersten okunduğunda sonraki beytin ilk kelime ya da hecesini ( راه / بهار) oluşturmaktadır. 
Rü 'yet-i hüsn-i hațuñ gonca-yı la' lin açar

Revnaḳ-1 rūy-1 nigār eyleye faṣl-1 bahār

Rāhber-i Hüsn ü ‘Așḳ oldı göñül şevḳ ile

Kim aña peyrev olur yolu selāmet çıkar

Rāḳ1-1 çeşm-i siyeh siḥr ile efsūn oḳur

Bir ḳıl ile bag̉lamış ‘āşıḳını ṣad hezār

Rāz-1 hevā bülbüle şīive-i hande güle

Rūz-1 ezel eylemiş böyle ḳader kirdgār

Rākid olur baḥr-i ' aş̣ vuṣlata irse göñül

Mevce gelir hecr ile olsa vezān rūzigār

Rākiz-i nabż-1 dilüm aldıñ ele ey țabīb

Söyleme bir kimseye derdümi bilmiş o yār

$\operatorname{Re}^{\prime} y-i$ vefă ‘ āşıḳa 'izzeti bādī olur

Bāg̀-1 murād içre gül goncası bahşs-1 mesār

Rāsim-i nakşs-1 nigār sīne-i gencīnede

Çīne çeker 'aşk ola perçemini şekl-i mār

Rām-1 lisānı olur her kime dilden eger

Eylese zülf-i siyeh ülfet ile i' tibār

Rābıt-1 dehr-i felek 'āşıkıını eglemiş

Besler anı şīr ile şīveler itsün nigār

Rākin-i bezm-i vișāl eyle desem dilbere

Hāżı̀r olur vușlata olmaya dil inkisār

Edebî Eleş̧iri Dergisi

Cilt 3, Sayn 1, Mart 2019 
Re's-i keremdür güzel ile niyāzum ḳabūl

Hुāṭır-1 mey al ele çekmeyesün bir ḩasār

Rāsih-i irfān olup kimseye ḩālüñ dime

Kāmì ḳanā' atda ol 'izzeti ḳ̂l ihtiyār

(Arslan, 2018: 75)

\section{Sonuç}

Kadim zamanlardan beri üslup; mimariden musikiye, hitabetten edebiyata kadar pek çok sahada kullanılmış ve her asırda yeni boyutlar kazanarak kullanılagelmiştir. Şiiri görsellikle buluşturan Şahin Giray'ın daha ziyade görselliğin ön plana çıktığı, müdevver, musanna ve deneysel şiir gibi kavramlarla da ifade edebileceğimiz şiir tarzı kendisinden sonraki bazı şairler tarafından benimsenmiş ve benzer tarzda şiirler yazma temayülleri oluşmuştur. Öyle ki Şaban Kâmî gibi müderris bir şair, Şahin Giray tarzı ile yazmış olduğu şiirlerine başlık olarak "Şahin Giray Üslubu" demekten çekinmemiştir. Bu çalışmada başta, Şahin Giray'ın kendisinden sonra gelen şairleri etkileyecek boyutta yazmış olduğu görsel şiirlerine yer verilmiş, daha sonra bu şiir tarzından etkilenerek Şahin Giray üslubu ile şiirler kaleme alan şairlerin şiir örnekleri tetkik edilerek, Şahin Giray'ın ifadeden ziyade şekilsel bir tarz/üslup oluşturduğu ve Osmanlı şiirine farklı bir soluk getirdiği kanaatine varılmıştır.

\section{KAYNAKÇA} Yayınlar1.

Arslan, Mustafa Uğurlu (2018). Diyarbekirli Kâmî ve Dîvânı, İstanbul: DBY

Aynur, Hatice (2009). "Türkî-i Basît Hareketini Yeniden Düşünmek"

Turkish Studies International Periodical For the Languages, Literature and History of Turkish or Turkic Volume 4/5 Summer, s. 35-59.

Avşar, Ziya (2001). “Türkî-i Basit’i Yeniden Tartışmak, Bilig-18/Yaz, s.127141.

Babacan, İsrafil (2012). Klasik Türk Şiirinin Son Baharı Sebk-i Hindi, Ankara.

Bilkan, Ali Fuat, Aydın, Şadi (2007). Sebk-i Hindi ve Türk Edebiyatından Hint Tarzı, İstanbul: 3F Yayınları.

Çavuşoğlu, Ali (2010). Kırım Hanı Şahin Giray (Ö. 1787) ve "Gazel-i Müdevver" $i$, Turan Stratejik Araştırmaları Merkezi Dergisi, C.II, S.8, Sonbahar.

Emecen, Feridun (2010). Şahin Giray, DİA, C.XXXVIII, İstanbul.

Elmalı, Naci (2015). Ketencizâde Ahmed Rüşdi Efendi, Erzurum: Atatürk Üniversitesi Yayınları.

İsmail Beliğ (1985). Nuhbetü'l-âsâr li-Zübdeti'l-eş'âr, Hazırlayan: Abdulkerim Abdulkadiroğlu, Ankara: Gazi Üniversitesi Yayınları. 
Kurnaz, Cemal - Çeltik, Halil (2000). Osmanlı Dönemi Kırım Edebiyatı, Ankara: Kültür Bakanlığı Yayınları.

Mazıoğlu, Hasibe (2012). Nedim 'in Divan Şiirine Getirdiği Yenilikler, Ankara: Akçağ Yayınları.

Mermer, Ahmet (2006). Türkî-i Basît ve Aydınlı Visâlı̂'nin Şiirleri, Ankara: Akçağ Yayınları.

Mehmet Süreyya (1996). Sicill-i Osmânî, Sebil Yayınları, C. III, İstanbul.

Öztürk, Sevgi (2012). Kırımlı Rahmi ve Divanı, Trakya Üniversitesi Sosyal Bilimler Dergisi Haziran C. XIV, S.1, s. 237-268. Ankara.

Şemsettin Sâmi (1996). Kâmûsü’l-A 'lâm C. IV, s.1740, Kaşgar Neşriyat.

Şenödeyici, Özer (2009). Osmanlının Görsel Şiirleri III, Trajedi'nin Gölgesinde Hüner Gösterisi, Uluslararası Sosyal Araştırmalar Dergisi, The Journal of International Social Research, Volume 2/6 Winter 2009, s. 586-592.

Tökel, Dursun Ali (2000). Deneysel Edebiyat Yönüyle Dîvân Şiiri, Ankara: Hece Yayınları.

Yorulmaz, Hüseyin (1996). Dîvân edebiyatında Nâbî Ekolü, İstanbul: Kitabevi Yayınları. 